\title{
An Empirical Investigation of the Relationship between Trade Liberalization and Poverty Reduction: A Case for Pakistan
}

\author{
Muhammad Shahbaz Akmal", Qazi Masood Ahmad**, Mohsin \\ Hussain Ahmad and Muhammad Sabihuddin Butt
}

\begin{abstract}
In this paper, we have addressed a key issue in the current debate on economic development: the effect of trade liberalization on poverty. We investigated the relationship between trade liberalization and poverty levels both in the long run as well as in the short run for Pakistan. To measure trade liberalization, we used standard indices of trade openness, financial openness and public intervention in the country, while the head-count ratio was used for poverty measurement, and GDP per capita controlled for economic growth. Applying the Johansen Co-integration Techniques and Error Correction Method, for long-run and short-run analyses respectively, our findings suggest that trade liberalization has a cumulative effect on poverty reduction in the long-run but not in the short run in Pakistan. Lower poverty is associated with low taxation and high foreign direct investment, while trade openness does not have a significant impact on poverty reduction, particularly in the short run, in Pakistan.
\end{abstract}

JEL Classification: F10, F13, I31

Keywords: Trade, Liberalization, Poverty

\footnotetext{
${ }^{*}$ Corresponding Author/Research Officer at Social Policy and Development Center, Karachi.

${ }_{* *}^{*}$ Associate Professor/President of Research Wing at Institute of Business Administration, University of Karachi.

*** Staff Economist/Assistant Professor at Applied Economics Research Centre, University of Karachi.

***** Associate Professor/Senior Research Economist at Applied Economics Research Centre, University of Karachi.
} 


\section{Introduction}

World trade has been increasing for centuries as explorers have discovered trade routes and the technology of transport has improved [David and Scott, (2005)]. The last two decades of the twentieth century observed a remarkable movement in the pace of openness or globalization. The integration of countries through flows of goods and services, financial assets, technology and cultural interaction has reached unprecedented levels [Stern, (2001)]. Now it is widely accepted that openness is as an important element of good economic policy and trade liberalization is a necessary step in achieving it [Obstfled and Rogoff, (1996); Winters, (2001); and Mackay and Winters, (2004)]. So the world is becoming more integrated, goods and trade in services are crossing borders in line with globalization and regionalization processes. Trade liberalization is generally an ally in the fight against poverty: it tends to increase incomes, provide more resources to tackle the problem of poverty and while it will generally affect income distribution, it does not do so in a systematically adverse way ${ }^{26}$ [Winters, (2001); and David and Scott, 2005)].

Economic theory gives many reasons for trade liberalization to enhance economic growth [Winters, (2002); Stern, (2001); Berg and Krueger, (2003); Mackay and Winters, (2004)]. By allowing easier imports of capital goods, greater allocative efficiency, technological and knowledge spillovers as well as increased competition, trade can enhance growth and also lead to the availability of a greater variety of goods to consumers at cheaper prices. The rewards from exploiting globalization can be substantial, since openness to international trade and investment facilitates the acquisition of inputs and technologies which strengthen growth and increase efficiency. Access to wider markets and more diverse exports reduces the risks of trade volatility and exclusion by particular country markets. Openness to the free flow of capital helps to attract FDI, which can stimulate domestic investment, thus contributing to employment generation and economic growth. Financial openness also helps to increase the depth and breadth of domestic financial markets, leading to increased efficiency in financial markets through lower costs and improved resource allocation, if financial markets are well developed [Obstfled and Rogoff, (1996); and Sharer et al, (1998)] $]^{27}$.

\footnotetext{
${ }^{26}$ Most trade liberalization will hurt some one, and that some reforms may increase overall poverty even while they boost incomes in total (Winters, 2003).

${ }^{27}$ Countries benefit from opening markets in many ways, one is technological: foreign direct investment which brings innovations in product, processes, and organizational technologies, while importation of goods bring embedded technologies and access-lower
} 
The debate about the impact of globalization on the well-being of people has generated a substantial literature. It is important to realize that the impact of trade liberalization on poverty is important because of the vulnerability of the poor in developing countries. It is widely argued by many commentators that in the short run, trade liberalization harms poor actors in the economy and even in the long run, successful open regimes may leave some people below the poverty line [Winters, (2002b) and Mackay and Winters, (2004)].

Recent work on this issue has concluded that the process of trade liberalization in Pakistan does not appear to have had a significant adverse impact on poverty, but these findings are not robust because the results are based on a single equation estimated by OLS (ordinary least square ${ }^{28}$. So the main purpose of this effort is to find the impact of trade liberalization on poverty reduction by applying the Johansen Co-integration Approach for the long-run and the Standard Error Correction Method (ECM) for the shortrun. The literature on trade liberalization emphasizes the elimination of distortions leading to both gains from trade and an increase in domestic economic activities leads ${ }^{29}$. To the extent the poor are also beneficiaries of these outcomes, poverty is expected to decline. This paper examines the impact of trade liberalization on poverty levels in the long-run as well as in the short run. The organization of the paper is as follows: Section II is a brief review of the literature, Section III explains the model and data collection procedure, Section IV describes the methodology and Section V presents the empirical results. Finally, Section VI gives the conclusions and policy recommendations.

\section{Literature Review}

Over the 1990s, the conviction that 'openness is good for growth' was fostered by several highly visible and well promoted cross country

cost production inputs and consumer goods. Another benefit is grater efficiency; competition from abroad spurs domestic industry to improve productivity, promote growth and increase employment in the medium term.

${ }_{28}$ They used IEL (Index of Economic Liberalization) as a proxy to measure openness which as a composite of four different outcome measures suffers from weakness inherent any aggregation scheme (SPDC's Annual Report, 2006).

29 Trade liberalization also leads to reduction in monopoly rents and the value of connections to bureaucratic and political power. In developing countries, it may be expected to increase the relative wages of lower-skilled workers (Berg and Krueger, 2003). 
studies [see Dollar (1992); Sachs and Warner (1995); Edwards (1998)] ${ }^{30}$. In the medium term, reaping static benefits of trade could look rather like growth. In the long run, potential positive forces include access to technology and appropriate intermediate and capital goods, the benefits of scale and competition, the flexibility induced by relying on market signals, and the constraint on government incompetence or corruption ${ }^{31}$ [Grossman and Helpman (1991); and Lucas, (1989)]. Unfortunately, none of the benefits is guaranteed and it is not difficult to construct a model in which openness pushes countries into less dynamic sectors e.g. primary extraction and harms growth [Rodriguez and Rodrik, (2001)]. The traditional theory of trade explained by Stolper-Samulson predicts that a rise in the relative price of a commodity leads to a rise in the real return to factors used intensively in producing that commodity [Dixit and Norman, (1980) $]^{32}$.

Further, liberal trade is usually one of several indicators of openness used, and one which often seems to weigh rather significantly in overall results [Harrison, (1996)]. An alternative approach is to specify the links between openness and growth and examine them separately. Some studies associated openness strongly with greater wealth accumulation [Levine and Renelt (1992); and Tylor (1998)] and stronger growth, especially over relatively short periods. Tilat (2002) found that openness has no robust link with long term growth and suggested that short-run effects out-weigh the perceived benefits of globalization, which means an increase in poverty and a lower economic growth rate. To investigate the relationships between trade openness, growth and poverty one must first consider the effects on

${ }^{30}$ Recently, they have been subjected to criticism and re-working by Rodriguez and Rodrik (2001), who argued that their conclusions rest on very weak empirical functions such as flawed measures of openness and serious econometric shortcomings.

${ }^{31}$ Wei (2000), on the other hand, suggests that losses from corruption increase with openness, because corruption impinges disproportionally on foreign transactions, and as a result open economies have greater incentives to develop institutions.

${ }^{32}$ Thus for a developing country with a highly protected production structure, liberalization will result a rise in the relative price of unskilled labor-intensive products (since skilledlabor or capital intensive imports become relatively less expensive when trade barriers are removed). As the market for labor-intensive products expands, so demand for unskilled labor will rise leading to higher returns to unskilled labor generally. The Stolper-Samulson theorem with the poor being equated with unskilled labor is preferred by many economists for trade. But for a variety of reasons spelt out in Winters(2000a), this approach is not equated and it is concluded that effects of trade reforms on income distribution will not generally be predictable. So the S-S theorem refers to change in the functional distribution of income, which is not necessarily related to household income changes (Geoffrey and Thugge, 2001). Because in many countries the poor are not just connected to labor markets for which it is possible to do Stolper-Samulson exercises and those labor markets do not display the required inelasticity of supply (Winters, 2002). 
total factor productivity [Winters, (2003)]. For sustained economic growth and development, improved productivity is necessary by universal agreement. It may not be sufficient and, because of its distributional implications, its beneficial effects on poverty could be less that those of growth emanating from other sources. For example, if higher productivity reflected declining inputs rather than increasing outputs, its short-run effects could be to reduce employment and exacerbate poverty.

Moreover, despite the strong presumption in modern growth theory, with its inferences to increased competition, access to new technologies, better intermediate goods and so on, the response of productivity to openness is ultimately ambiguous. A sceptical view of the early literature on this link is Pack (1988). An influential study by Coe, Helpman and Hoffmaister (1997), constructed an index of the total knowledge capital (measured by accumulated investment in R\&D) in each industrial country. Using an import-weighted sum of industrial countries knowledge stocks to reflect developing countries access to foreign knowledge, they find that, interacted with importing countries openness, the latter has a significant positive effect on total factor productivity. Lumenga-Neso Ollarreaga and Schiff (2001), advance the theory that indirect knowledge flows offer a better explanation of TFP. Many studies show that reduction in trade barriers were followed by significant increases in TFP, generally because of increased import competition [Ferreira and Rosi (2001) in Brazil; Jonsson and Subramanian ${ }^{33}$ (2001) for South Africa; Lee (1996) for Korea and Fatima et al (2003) for Pakistan]. While Begstien et al (2000) find a positive stimulus from exports to productivity in Africa, Karry (1997) obtain ambiguous results for China, while Aw, Chung and Roberts (1999) find little evidence for it in Latin America and Asia respectively. Historically, there has been significant debate about whether agricultural improvements are good for the poor, but recently the tendency has been on the optimistic side [see, for example, Datt and Ravallion (1998)].

Overall empirical evidence suggests that trade liberalization has a strong influence on productivity and its rate of change (Fatima et al, 2003). In many cases, the latter will be immediately and directly povertyalleviating and in the long-run, they are a necessary part of any viable poverty reduction strategy. Also it is not difficult to imagine adverse shortrun implications for jobs and poverty. Trade liberalization is usually associated with higher flows of foreign direct investment with attendant spillovers of technologies, new business practices and other effects in

\footnotetext{
${ }^{33}$ Johansson and Subramanian also conducted a time series exercise which links TFP positively to the openness ratio-exports + imports/GDP.
} 
domestic firms that increase the overall level of productivity and growth and also alleviate poverty levels [Hay (2001); Ferreira and Rosi (2001)]. A very important concern about openness is that it will reduce government revenues. The share of trade taxes in total revenue is negatively associated with the level of economic development, with many low-income countries earning half or more of their revenues from trade taxes ${ }^{34}$. Neither theory nor evidence suggests a simple link between trade liberalization and revenues, however in theory, a number of factors are important (Greenway and Milner, 1991). In the case of tariffs, revenues will increase with liberalization if the initial tariff level exceeds its revenue maximizing level $^{35}$. Falvey (1994) explains that a Welfare Improving Revenue Enhancing (WIRE) tariff will always exist unless the compensated radial elasticities of all goods are the same. However, designing such as package is well beyond most governments' capabilities, especially since long and short-run responses may differ (e.g. Baven 2000). The alternative response to a fall in revenues is to cut public expenditures. There is a vast literature describing the effects of structural adjustment in developing countries on poverty and the impact felt through public expenditures and social sector expenditures in particular ${ }^{36}$. But evidence from adjustment resulting in cuts in social expenditures is mixed at best (Van der Gaag, 1991). Van der Gaag examines spending in the three years before and after donor financed adjustment programs began, and find, no pattern of increase or decrease in real total levels and social sector expenditures. Similarly, Sahn et al (1997) argued that, except in a few cases, those declines in social expenditures that have occurred have not been "part of the extended attempt to balance the government's fiscal position.”

\section{Model and Data}

The model under consideration envisages an inverse relationship between openness and poverty levels, therefore various indices on openness are taken as independent variables (FDI, TRADE and Tax) while GDP per

\footnotetext{
${ }^{34}$ This reliance may reflect various factors, including difficulties in administering a tax system effectively and the relatively small share of the formal sector (Ebrill, Stotsky and Gropp, 1999).

${ }^{35}$ The revenue maximizing tariff will be $t=\left(\varepsilon_{s}-\varepsilon_{d}\right) /-\varepsilon_{s}\left(1+\varepsilon_{d}\right)$ where $\mathrm{t}$ is the ad valorem tariff rate, $\varepsilon_{s}$ is the elasticity of import supply and $\varepsilon_{d}$ is the elasticity of import demand (Ebrill, Stotsky and Gropp, 1999)

${ }^{36}$ Kellick (1995) provides an excellent brief review of the findings of such work; White (1997) provides comprehensive review of literature, while Squire (1991) and Van der Hoeven (1996) provide reviews of linkage between adjustment and poverty in the 1980s.
} 
capita is included as a control variable for the basic specification of the model below;

$$
P o v=\beta_{\circ}+\beta_{1} F D I+\beta_{2} T A X+\beta_{3} T R A D E+\beta_{4} G D P_{P C}+v_{t}
$$

Where the dependent variable is the poverty index ${ }^{37}$ (Head-Count). Amjad and Kemal (1997) explained poverty trends in Pakistan with the help of macroeconomic determinants. Using simple econometric techniques Akhter and Ahmad (1999) extended the work of Amjad and Kemal (1997) conceptually and explained poverty trends in the country. For the estimation of time series data, a simple interpolation technique is applied to take the decline or growth in trend between two points in time and fill the data gaps between successive observations (Jamal, 2004). Moreover, for international economic institutions such as the World Bank and government development agencies such as DFID, which are concerned with poverty in developing as well as in developed countries, the absolute measure is more appropriate than relative ones.

An indicator that has received only scant attention from economic theorists is the degree of openness [Harrison, (1996)]. For trade openness of an economy, we use (Import + Export) as share of $\mathrm{GDP}^{38}$. Foreign Direct Investment (FDI) is a proxy of financial openness which measures the medium and long-term ability of a country to attract investment from abroad $^{39}$ because FDI is an important source of capital, complements domestic private investment, is usually associated with new job creation and enhancement of technology transfer and boosts overall economic growth in host countries ${ }^{40}$. Globalization is not solely openness to international trade, although this is probably its most important feature.

\footnotetext{
${ }^{37}$ Malik (1988) first generated five poverty observations during the period of 1963-64 to 1984-85 on the basis of household surveys using consistent indices to compute poverty lines for these particular years (defining the poverty line based on caloric requirement of 2250 plus basic needs of a person).

${ }^{38}$ The relevant question in the case of this indicator is not only what a country exports but also how it exports and imports in relation to its GDP.

${ }^{39}$ The most sceptical view of the openness process blames the liberalization of global financial markets for their allegedly negative effects in terms of increase in financial speculation, unemployment and poverty. For example, studies collected by Cornia and Lipumba (1999), show that, in the case of Africa, liberalization of financial markets has attracted large short-run speculative in flows which included large saving in nominal and real exchange rates. A major result of such speculative movements is a lack of adequate incentives to potential private investors in the tradable sector.

${ }^{40}$ For a comprehensive survey of the nexus between FDI and growth as well as for further evidence on the FDI-growth relationship see Mody and Murshid (2002). See Chakrabarti (2001) on the determinants of FDI.
} 
The liberalization of financial markets has brought about a huge increase in capital inflows, particularly in the form of foreign direct investment. So FDI can be used to interpret financial openness (Figini et al, 2004) ${ }^{41}$. Tax revenue changes might have different impacts on poverty according to how progressiveness is modified and whether or not these changes take place in the framework of macroeconomic stabilization policies. To control for the latter, it is important to deal with the complementary measures that may have been implemented to tackle both macroeconomic instability and adverse effects of adjustments and stabilization programmes. Tax revenue is used as a proxy for the 'role of the state'. The data has been taken from the IFS (International Financial Statistics), WDI (World Development Indicators) and Economic Survey of Pakistan (various issues), for the period 1973-2003.

\section{Methodology}

When testing time-series properties and co-integration evidence, the preliminary step in that analysis is concerned with establishing the degree of integration of each variable. The distinction between whether the levels of differences of a series is stationary leads to substantially different conclusions and hence, tests of non-stationarity ${ }^{42}$ (that is unit roots) are the usual practice today. Engle-Granger (1987), define a non-stationary time series to integrated of order ' $d$ ' if it becomes stationary after being differentiated ' $d$ ' time. This notion is normally denoted by $I(d)$.

The test for co-integration proceeds in two steps: first, the individual series are tested for a common order of integration. If the series are integrated and are of the same order, it would imply co-integration. Using the Augmented Dickey Fuller (ADF) test, the stationarity of the series is tested. The ADF test is a standard unit root test; it analyzes the order of integration of the data series. These statistics are calculated with a constant and a constant plus time trend and these tests have a null hypothesis of non-stationarity against an alternative of stationarity. The

\footnotetext{
${ }^{41}$ We also know that this measure does not fully account for both levels of financial openness: capital account liberalization and national treatment of foreign banks and other operations of entering in the local markets.

${ }^{42}$ Stationarity tests are of particular importance for at least two reasons: (i) the statistical theory underlying time-series analysis relies on the assumption of co-variance stationarity, an assumption that is, more of less than not, found to be violated in many economic time series; and (ii) failure to account for stochastic trends in the data series means mis-specifying the model. Clearly this can seriously affect statistical inferences and hypothesis tests.
} 
$\mathrm{ADF}$ test to check the stationarity series is based on the equation of the form given below:

$$
\Delta y_{t}=\beta_{1}+\beta_{2} t+\delta y_{t-1}+\alpha_{i} \sum_{t=1}^{m} \Delta y_{t-1}+\varepsilon_{t}
$$

Where $\varepsilon_{t}$ is a pure white noise error term and

$$
\Delta y_{t-1}=\left(y_{t-1}-y_{t-2}\right), \Delta y_{t-2}=\left(y_{t-2}-y_{t-3}\right), \quad \text { etc. }
$$

These tests determine whether the estimates of $\delta$ are equal to zero. Fuller (1976) provided a cumulative distribution of the ADF statistics; if the calculated-ratio (value) of the coefficient $\delta$ is less than $\tau$ the critical value from the Fuller table, then $\mathrm{Y}$ is said to be stationary ${ }^{43}$.

Consider for example two series $X_{t}$ and $Y_{t}$ both integrated of order (d). Engle and Granger have described that their linear combination will in general also be $\mathrm{I}(\mathrm{d})$.

It is an empirical fact that many macro economic variables appear to be integrated of order (d) [or I(d) in the terminology of Engle and Granger (1987)] so that their changes are stationary. Hence, if POV, TAX, FDI, TRADE and GDP per capita are each I(d), then it may be true that any linear combination of these variables will also be $\mathrm{I}(\mathrm{d})$. Having established that all of these variables are $\mathrm{I}(\mathrm{d})$, this study then proceeds to determine the order of integration of series for the analysis of long-run relationships between POV, TAX, FDI,TRADE and GDP per capita. For the purpose of examining the long-run relationship among the variables, they must be co-integrated. Two or more variables are said to be cointegrated if their linear combination is integrated to any order less than ' $d$ '. The co-integration test provides the basis for tracing the long-run relationship. Two tests for co- integration have been given in the literature [Engle and Granger (1987) and Johansen and Juselius (1990)]. In the multivariate case, if the $\mathrm{I}(1)$ variables are linked by more than one cointegrating vector, the Engle-Granger procedure is not applicable. The test for co-integration used here is the likelihood ratio put forward by Johanseen and Juselius (1990), indicating that the maximum likelihood method is more appropriate in a multivariate system. Therefore, this study has used this method to identify the number of co-integrated vectors in the model. The Johansen and Juselius method has been developed in part

43 ' $\mathrm{t}$ ' ratio of coefficient $\delta$ always has a negative sing. 
by the literature available in the field and reduced rank regression, and the co-integrating vector ' $r$ ' is defined by Johansen as the maximum Eigenvalue and trace test or statics. There are ' $r$ ' or more co-integrating vectors. Johansen (1988) and Johansen and Juselius (1990) proposed that the multivariate co-integration methodology could be defined as:

$$
\mathrm{S}_{\mathrm{t}}=\left(\mathrm{POV}, \mathrm{FDI}, \mathrm{TAX}, \text { TRADE and } G D P_{P C}\right)
$$

which is a vector of $P=5$ elements. Considering the following autoregressive representation:

$$
S_{t}=\pi_{\circ}+\sum_{T=1}^{K} \pi_{i} S_{t-1}+\mu_{t}
$$

Johansen's method involves the estimation of the above equation by the maximum likelihood technique, and testing the hypothesis $\mathrm{H}_{\mathrm{o}}$; $(\pi=\Psi \xi)$ of " $\mathrm{r}$ " co-integrating relationships, where $\mathrm{r}$ is the rank or the matrix $\pi(0 \angle r \angle \mathrm{P}), \Psi$ is the matrix of weights with which the variable enter co-integrating relationships and $\xi$ is the matrix of co-integrating vectors. The null hypothesis of non-cointegration among variables is rejected when the estimated likelihood test statistic $\phi_{i}\left\{=-n \sum_{t=r+1}^{p} \ln \left(1-\hat{\lambda}_{i}\right\}\right.$ exceeds its critical value. Given estimates of the eigen-value $\left(\hat{\lambda}_{i}\right)$ the eigen-vector $\left(\xi_{\mathrm{i}}\right)$ and the weights $\left(\Psi_{\mathrm{i}}\right)$, we can find out whether or not the variables in the vector $\left(S_{t}\right)$ are co-integrated in one or more long-run relationships among (POV, FDI, TAX, TRADE and GDP per capita). Having established the relationship among the variables, the question that remains is if in the short run there is disequilibrium or not. To find the effect of short-run changes of (FDI, TRADE, TAX and GDP per capita) on poverty, we used the following specification:

$$
\begin{aligned}
& \Delta P=\gamma+\alpha \eta_{t-i}+\sum_{i=1}^{p} \beta_{P} \Delta P_{t-i}+\sum_{i=1}^{p} \beta_{T R A D E} \Delta T R A D E_{t-i}+\sum_{i=1}^{p} \beta_{F D I} \Delta F D I_{t-i} \\
& +\sum_{i=1}^{p} \beta_{T A X} \Delta T A X_{t-i}+\sum_{i=1}^{p} \beta_{G D P P C} \Delta G D P P C_{t-i}+v_{t}
\end{aligned}
$$

Where $v_{t}$ is the error term and $\alpha$ is short run speed of adjustment, 
Johansen and Juselius (1990) provide critical values for the two statistics. The statistical distribution depends on the number of nonstationary components in the model. To determine the non-stationary components, it is necessary to choose the lag length for the VAR portion of the model. To overcome this problem, this work determines the optimal lag length using Akaike's Information Criterion (AIC) and Schwartz Bayesian Criterion $(\mathrm{SBC})^{44}$. The lowest values of $\mathrm{AIC}$ and $\mathrm{SBC}$ are used to select the lags and give the most desirable results.

\section{Empirical Analysis}

Since the present study is an initial attempt to identify the links between the evolution of poverty and trade liberalization (the phenomenon related to openness) in the case of Pakistan, we empirically estimated whether a statistically significant relationship exists between some measures of trade liberalization and poverty levels in the long-run as well as in the short-run. The preliminary step in this analysis is concerned with establishing the degree of integration of each variable. For this purpose, to get reliable results of equation 1 , the implicit assumption is that variables in equation 1 are I(1) and co-integrated. We apply the test for the existence of a unit root in the level and first difference of each of the variables in our sample using the Augmented Dickey Fuller (ADF) test. ADF test statistics check the stationarity of series. The results presented in Table-1 reveal that all other variables are non-stationary in their level data. However, stationarity is found in the first differencing level of the variables Poverty, Foreign Direct Investment, Tax Revenue as share of GDP, Trade and GDP per capita.

\footnotetext{
${ }^{44}$ The distribution of the test statistic is sensitive to the order of lag used. If the lag order is used less than the true lag, then the regression estimates will be biased and the residual terms will be serially correlated. If the order of lag used exceeds the true order, the power of the test is to be reduced.
} 
Table-1: Unit Root Estimation

\begin{tabular}{lcccc}
\hline & \multicolumn{2}{c}{ Level } & \multicolumn{3}{c}{$\mathbf{1}^{\text {st }}$ Difference } \\
\hline \multicolumn{1}{c}{ Variables } & Constant & $\begin{array}{c}\text { Constant } \\
\text { and Trend }\end{array}$ & $\begin{array}{c}\text { Constant } \\
\text { and Trend }\end{array}$ & $\begin{array}{c}\text { Constant } \\
\text { and Trend }\end{array}$ \\
\hline Poverty & -3.08 & $3.98^{* *}$ & $3.98^{* *}$ & $-5.59^{*}$ \\
Trade & -2.35 & -2.77 & -2.77 & $-4.50^{*}$ \\
Foreign Direct Investment & -1.80 & -2.59 & -2.59 & $-5.11^{*}$ \\
Tax Revenue as share of GDP & -2.16 & -1.85 & -1.85 & $-4.76^{*}$ \\
GDP per capita & 0.29 & -2.51 & -2.51 & $-5.35^{*}$ \\
\hline
\end{tabular}

Note: * significant at $1 \%$

** Due to some problems in the data for poverty, the variable is stationary with a constant at lag (0) while with constant and trend becomes nonstationary so this variable is also stationary at $1^{\text {st }}$ difference with lag (1).

Table-2

\begin{tabular}{cccc}
\hline $\begin{array}{c}\text { Orders of } \\
\text { Lags }\end{array}$ & $\begin{array}{c}\text { Akaike's Information } \\
\text { Criteria }\end{array}$ & $\begin{array}{c}\text { Schwartz } \\
\text { Bayesian Criteria }\end{array}$ & $\begin{array}{c}\text { Log } \\
\text { Likelihood }\end{array}$ \\
\hline 1 & 5.3479 & 6.7491 & -50.2187 \\
2 & -0.1216 .11 & 2.4715 & 56.76332 \\
\hline
\end{tabular}

Chow Break test $\left(\mathrm{F}\right.$ statistic $\left.=62.5824^{45}\right)$

${ }^{45}$ F-value shows that we reject Null Hypothesis, indicating a structural change in the economy started in 1990s, especially the reforms in the financial sector and other sectors under SAP (Structural Adjustment Program approved by IMF to be implemented in Pakistan). 
Table-3: Johansen-Juselius First Information Maximum Likelihood Test for Co-integration

\begin{tabular}{cccccccc}
\hline $\begin{array}{c}\text { Null- } \\
\text { Hypothesis }\end{array}$ & $\begin{array}{c}\text { Trace- } \\
\text { Test } \\
\text { values }\end{array}$ & $\begin{array}{c}5 \text { Percent } \\
\text { Critical } \\
\text { Value }\end{array}$ & $\begin{array}{c}\text { 1 Percent } \\
\text { Critical } \\
\text { Value }\end{array}$ & $\begin{array}{c}\text { Null- } \\
\text { Hypothesis }\end{array}$ & $\begin{array}{c}\text { Maximum } \\
\text { Eigen } \\
\text { values }\end{array}$ & $\begin{array}{c}5 \text { Percent } \\
\text { Critical } \\
\text { Value }\end{array}$ & $\begin{array}{c}\text { 1 Percent } \\
\text { Critical } \\
\text { Value }\end{array}$ \\
\hline$R=0$ & $197.70^{*}$ & 87.31 & 96.58 & $R=0$ & $90.85^{*}$ & 37.52 & 42.36 \\
$R \leq 1$ & $106.85^{*}$ & 62.99 & 70.05 & $R=1$ & $58.98^{*}$ & 31.46 & 36.65 \\
$R \leq 2$ & $47.86^{* *}$ & 42.44 & 48.45 & $R=2$ & $27.15^{* *}$ & 25.54 & 30.34 \\
$R \leq 3$ & 20.71 & 25.32 & 30.45 & $R=3$ & 13.87 & 18.96 & 23.65 \\
$R \leq 4$ & 6.84 & 12.25 & 16.26 & $R=4$ & 6.84 & 12.25 & 16.26 \\
\hline
\end{tabular}

Note: ${ }^{*}(*)$ represent significant at $1 \%(5 \%)$, Johansen Co-integration test provides three Co-integrating equations at $1 \%$ and $5 \%$ significant levels.

After establishing that all the individual series under consideration are stationary, the traditional co-integration method is used to estimate the long-run relationship among the variables, particularly poverty, foreign direct investment, tax revenue as share of GDP trade, and GDP per capita. As mentioned above, Johansen's maximum likelihood approach is being applied for the co-integration test ${ }^{46}$.

The results from the Johansen Co-integration analysis are summarized in Table-3, where both the maximum eigen value and trace-test value examine the null hypothesis of no co-integration against the alternative of cointegration. Starting with the null hypothesis of no co-integration $(R=0)$ among the variables, the trace-test statistics is 197.7 , which is above the $1 \%$ and $5 \%$ critical values 96.58 and 87.31 respectively. Hence it rejects the null hypothesis $R \leq 0$ in favor of the general alternative $R=1$. As is evident in Table-3, the null hypothesis of $R \leq 1$ can be rejected at the $1 \%$ level of significance, hence its alternative of $R=2$ is accepted. Consequently, we conclude that there are three co-integrating relationships among poverty, foreign direct investment, tax revenue as share of GDP, trade as share of GDP and GDP per capita. Turning to the maximum eigen value test, the null hypothesis of no co-integration $(R=0)$ is rejected at the $1 \%$ level of significance in favor of the alternative, that is one co-integrating vector, $R=1$. The test also rejected the null hypothesis of $R=1$ in favor of the alternative $R=2$. This is the confirmed conclusion overall that there are three co-integrating relationship amongst the five I(1) variables. Therefore, ${ }^{46}$ Optimal lag length is (2) selected using Akakie's information criterion (AIC) and
Schwartz criterion (SIC) as shown in Table-2. 
analysis of annual data from 1973 to 2003 appears to support the proposition that there exists a stable long-run relationship among foreign direct investment, tax revenue as share of GDP, trade as share of GDP, poverty, and GDP per capita in Pakistan. Once co-integration is established, then an Error Correction Method (ECM) can be estimated to determine the short-run behavior of trade liberalization (foreign direct investment, tax revenue as share of GDP, trade as share of GDP) and GDP per capita on the poverty rate. Results of the ECM are presented in Table-4.

Table-4: Short-Run Error Correction Model: Dependant variable = Poverty Index (Head-count Ratio)

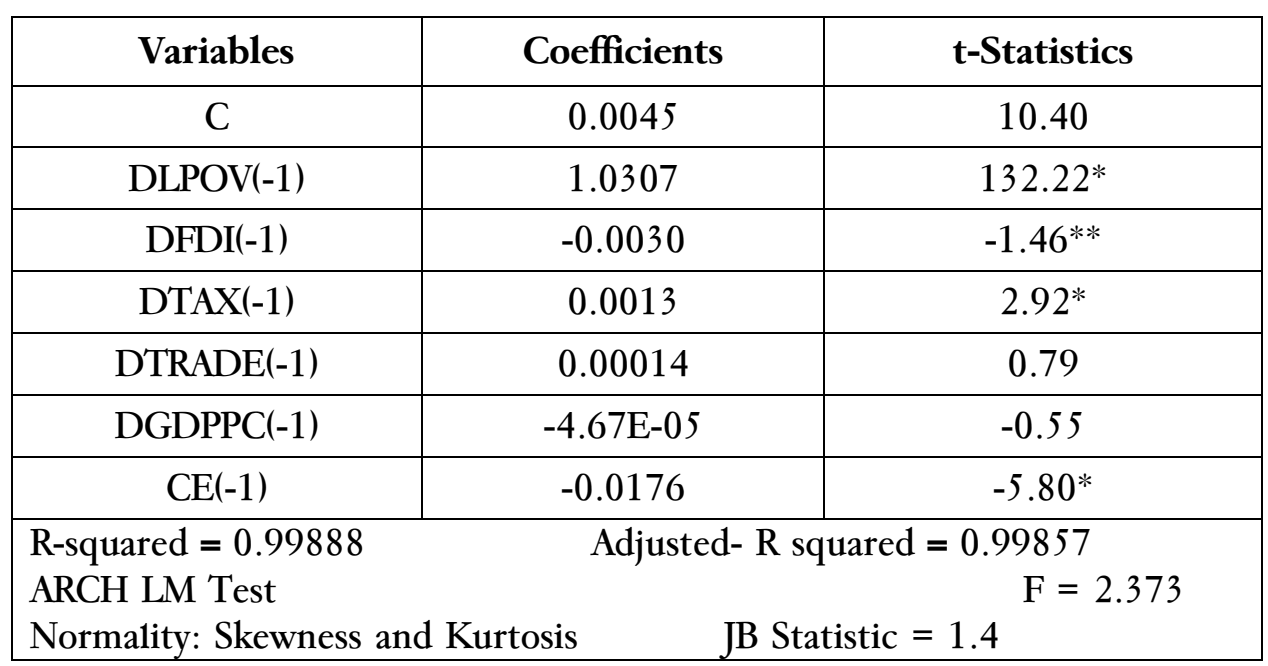

Note: ${ }^{*}(*)$ represents the coefficients are statistically significant at $1 \%$ (and $10 \%)$ levels. Ramsey's test is for functional from Mis-specification and JarqueBara test for non-normality of errors.

Table-4 reports the results of the ECM (Error Correction Mode1) formulation of equation 4. According to Engle-Granger (1987), co-integrated variables must have an ECM representation. The ECM strategy provides an answer to the problem of spurious correlation, the short run dynamic relationship between trade liberalization and the poverty rate estimated from the ECM formulation. The long run dynamics appear in the set of regressors. Technically, ECM (Error Correction Term) measures the speed of adjustment back to co-integrated relationships. The ECM is posited to be a force returning the integrated variables to their long-run relation when they deviate from it and thus the longer the deviation, the greater would be the force tending to correct the deviation [Banerjee, et al, (1994)]. The coefficients of lagged values of $\triangle P, \triangle F D I, \triangle T A X, \triangle T R A D E$ and $\triangle G D P_{P C}$ are short run 
parameters measuring the immediate impact of the independent variables on $\triangle P$. In equation 4 , the coefficients of lagged values of $\triangle T R A D E$ and $\triangle G D P_{P C}$ are statistically insignificant showing no impact on the poverty rate in the short run. The coefficients of lagged values of $\triangle F D I$ and $\triangle T A X$ are statistically significant, indicating the immediate impacts on the poverty rate in short-run dynamics. Whereas the value of $C E_{t-1}$ (Error Correction Term of the equation) is statistically significant at $1 \%$ suggesting powerful long run corrections in the model each year. Overall, our results support the hypothesis that trade liberalization alleviates poverty mostly in the long run. The shortrun diagnostic test shows non-normality of errors, while the ARCH test shows no second order serial correlation in the short-run model.

Table-4 also shows that FDI has a negative sign with a statistically significant value i.e. FDI is associated with lower levels of poverty while the TAX (role of government or public intervention) variable has a positive and significant value which means that a tax increase is linked with a higher incidence of poverty in the long run as well as in the short run. FDI and TAX can be regarded as an argument in support of openness. The variable $G D P_{P C}$ is included in the model as a control variable for the level of development in the country, which is negatively linked to poverty but not significant in the short run, which emphasizes that economic growth is not pro-poor.

While the variable $\operatorname{TRADE}^{47}$ has a positive sign, it is not statistically significant in the short run which does not support the openness theory. This may be the result of the fact that our exports are cotton based and mainly depend on the climate. Therefore, increases in export prices in international markets do not have a significant impact on the incomes of peasants because of disguised unemployment and underemployment in the agricultural sector, a major contributor to GDP, and secondly, because of the unequal distribution of land holdings. Benefits are reaped by big landowners due to an increase in the price of cotton in national and international markets and the peasants remain poor, thus contributing to rural poverty.

\section{VI: Conclusions and Policy Recommendations}

In the present study we have focused on a key issue in the current debate on economic development: the effect of trade liberalization on poverty levels in the case of Pakistan. We empirically tested the relationship between trade liberalization and poverty levels both in the long run as well

\footnotetext{
${ }^{47}$ See Social Poverty and Development Center's Annual Report (2006).
} 
as in the short run. To measure trade liberalization, we used standard indices of trade openness, financial openness and public intervention in the country, while head-count ratios were used for poverty measurement and GDP per capita was controlled for economic growth.

Our results imply that trade liberalization reduces poverty levels in the long run, while in the short run financial openness lowers poverty and the size of government (or public intervention) is associated with higher poverty levels, supporting the argument of openness. Neither trade openness nor GDP per capita has a significant relation with poverty in the short run. To achieve the major objective of reducing poverty, the government needs to design and implement an active development strategy not only to benefit from openness, but also to help counteract the negative effects of openness. Openness should not be viewed as a reliable substitute for a domestic development strategy but should be accompanied by improved trade-related infrastructure [Dollar and Kraay, (2001)]. Instead, the government needs to pursue more active trade liberalization and active domestic development policies which may benefit more poor people in the country. The government should focus on promoting foreign direct investment, which will be a complementary requirement for trade liberalization to be successful for the promotion of exports.

There is also a need to enhance the tax revenues of the state through better collection of revenues, and administrative reforms rather than expenditure cut backs, which can reduce the effectiveness of the public sector. The government needs to adopt a new approach of allocation of funds to social sectors so as to bring the issue of poverty reduction to the central stage of economic policy making. There is also the need for a realistic assessment of poverty for an effective poverty reduction strategy. More reforms in the banking sector are needed to enable the poor to get access to easy credit because the poor have small/few assets and are unable to meet their consumption needs during even short spells of unemployment. Thus, short run adjustment will not only increase poverty but also raise the intensity and severity of poverty among the poor. Trade policy reforms have the potential for improving growth and development and thus alleviating poverty in Pakistan with the adoption of some new distribution measures. Potential gains from trade liberalization are not automatic or guaranteed and trade reform policies do not alone reduce poverty. It is necessary to formulate macroeconomic policies, including trade reform policies, and introduce complementary options to create a paradigm shift in the right direction to empower more people with opportunities to eradicate poverty. Trade reforms must be pro-poor and geared to help the poorest of the poor. 


\section{References}

Akhtar, S. and Mansoor Ahmad, 1999, "Modelling Poverty Trends in Pakistan”. Research Report no.27, Social Policy and Development Centre.

Ambreen F, Shaista, Alam and M.S Butt, 2003, "International Trade and Productivity Growth”, Indian Journal of Quantitative Economics, pp: $35-53$.

Amjad and A .R. Kema1, 1997, "Macroeconomic Policies and their Impact on Poverty Alleviation in Pakistan Development”.36(1), pp.39-68.

Anwar, T, 2001, "Impacts of Globalization and Liberalization on Growth, Employment and Output" Helsinki, WIDER-United Nations University.

Aw, B.Y., Chung, S. and Roberts, M.J. 1999, "Productivity and Turnover in the Export Market: Micro Evidence from Taiwan and South Korea", NBER, February 1999.

Banerjee, A. V. and A. F. Newman 1994, "Poverty, Incentives and Development”, American Economic Review, 84(2), pp. 211-215.

Bevan, D. 2000, 'Fiscal Implications of Trade Liberalization' in Bevan, D. et al (eds.). Trade and fiscal adjustment in Africa, New York: St. Martin's Press.

Chakrabarti, A. 2001, "The Determinants of Foreign Direct Investment: Sensitivity Analysis of Cross-Country Regressions”, KYKLOS, 54, pp. 89-114.

Coe, David T., Helpman, Elhanan and Hoffmaister, Alexander W. 1997, "North-South R\&D Spillovers", Economic Journa1, 107(44) (January 1997): 134-49.

Cornia and Lipumbia, 1999, "The Impacts of Globalization of the Exchange Rate and Financial Markets in Sub-Saharan Africa". Journal of Development Economics, 11(13).

Datt, G. and M. Ravallion, 1998, "Farm Productivity and Rural Poverty in India", The Journal of Development Studies, 34(4), April 1998, pp. 62-85. 
David and Schott, 2005, "Macroeconomics: Understanding the Wealth of Nations, A Handbook Published by John Welly \& Sons: Ed. New York.

Dollar, David 1992, "Outward-Oriented Developing Economies Really Do Grow More Rapidly: Evidence from 95 LDCs, 1976-1985”, Economic Development and Cultural Change, 40(3), pp. 523-44.

Dollar, David and Kraay, Aart 2002, "Growth is Good for the Poor", Journal of Economic Growth (US); 7, No. 3:195-225.

Ebrill, L.; J. Stotsky and R. Gropp 1999, "Revenue Implications of Trade Liberalization”, Occasional Paper 42, IMF, Washington DC.

Engle, R F. and Granger, G.W.J, 1987, "Co-integration and Error Correction: Representation, Estimation and Testing”. Econometerica, 55, 251-276.

Falvey, R. 1994, "Revenue Enhancing Tariff Reform”, Weltwirtschaftliches Archiv 130(1): 175-90.

Ferriera, Pedro C. and Rossi, L. 2001, "New Evidence on Trade Liberalisation and Productivity Growth", Ensaios Economicos da EPGE 433.

Geoffrey and Thugge, 2001, "International Trade and Poverty" IMF $\mathrm{WP} / 01 / 54$.

Greenaway, D. and C. Milner 1991, "Fiscal dependence on trade taxes and trade policy reform”, The Journal of Development Studies 27(April): 95-132.

Grossman, G. M. and E. Helpman 1991, Innovation and Growth in the Global Economy, Cambridge, Mass and London: MIT Press.

Haroon, J., 2004, “Does Inequality Matters for Poverty Reduction? Research Report no.58, Social Policy and Development Centre.

Harrison, Anne 1996, "Openness and Growth: A Time-Series, Cross-Country Analysis for Developing Countries”, Journal of Development Economics, 48(2) (March 1996): 419-47.

Johansen S. 1988, "Statistical Analysis of Co-integration Vectors" Journal of Economic Dynamic and Control, 12, pp.231-254. 
Johansen S. and K. Juselies, 1990, "Maximum Likelihood Estimation and Inferences on Co-integration" Oxford Bulletin of Economics and Statistics, 52, pp.169-210.

Jonsson, G. and Subramanian A. 2001, "Dynamic Gains from Trade: Evidence from South Africa”, IMF Staff Papers, 48(1), pp. 187-224.

Killick, T. 1995, "Structural Adjustment and Poverty Alleviation: An Interpretative Survey", Development and Change 26: 305-331.

Kraay, A. 1997, "Exports and economic performance: evidence from a pane1 of Chinese enterprises", mimeo, Development Research Group, The World Bank.

Krueger and Berg, 2003, "Trade, Growth, Poverty" IMF WP/03/30.

Krueger, A. O. 1985, Trade and Employment in Developing Countries, Volume 3: Synthesis and Conclusions, Series: (NBER-M) National Bureau of Economic Research Monograph.

Lee, J-W. 1996, "Government Interventions and Productivity Growth", Journal of Economic Growth, 1 (3): 391-414.

Lumenga-Neso, A.; M. Olarreaga and M. Schiff 2001, "On 'Indirect' TradeRelated R\&D Spillovers and Growth”, CEPR Discussion Paper 2871, London.

Malik, Mohammad Hussein, 1988, "Some New Evidence on the Incidence of Poverty in Pakistan”, Pakistan Development Review, 27(4), pp:P509-16.

Obstefled and Rogoff, 1996, Foundations of International Macroeconomics. Cambridge MIT Press.

Pack, H. 1988, "Industrialization and Trade" in H. Chenery and T.N. Srinivasan (eds.), Handbook of Development Economics, Volume I, Elsevier Science Publishers B.V.

Rodriguez, F. and D. Rodrik, 2001, "Trade Policy and Economic Growth: A Sceptic's Guide to the Cross-national Evidence”, NBER Macroeconomics Annual 2000, Cambridge, Mass., MIT Press, pp. 261-324. 
Sachs, Jeffrey D. and Warner, Andrew M. 1995, "Economic Convergence and Economic Policies", Brookings Papers in Economic Activity, (1), pp. 1-95.

Sahn, D. E.; P. A. Dorosh and S. Younger 1997, Structural Adjustment Reconsidered: Economic Policy and Poverty in Africa, Cambridge, Cambridge University Press.

Santare1li, E and P. Figini, 2004, "Does Globalization Reduce Poverty?". mimeo

Sharer, Robert, and others, 1998, "Trade Liberalization In IMF-Supported Programs, World Economic and Financial Survey (Washington: International Monetary Fund).

Squire, L. 1991, "Introduction: Poverty and Adjustment in the 1980s", The World Bank Economic Review 5(2): 177-185.

Stern, N., 2001, "Globalization, Investment Climate and Poverty Reduction, Mimeographed.

Taylor. A.M. 1998, "On the Costs of Inward-Looking Development: Price Distortions, Growth and Divergence in Latin America”, The Journal of Economic History, 58 (1): 1-28.

Van der Gaag, J. 1991, "Poverty in the Developing World: Assessment of the Past, Prospects for the Future”, European Economic Review ,35, pp. 343-349.

Van der Hoeven, R. 1996, "Structural Adjustment and Poverty: Review of Experiences in the 1980s"in C. H. Hanumantha Rao and H. Linnemann (eds) Economic Reforms and Poverty Alleviation in India, Sage Publications: 90-118.

Wei, Shang-Jin 2000, "Natural Openness and Good Government", National Bureau of Economic Research Working Paper 7765 (June 2000).

White, H. 1997, Poverty and Adjustment in Sub-Saharan Africa: A Review of the Literature. The Hague, Institute of Social Studies.

Winters and Mackay, 2004, "Trade liberalization and Poverty: The Evidence So Far", Journal of Economic Literature, 42(1), pp:72-115.

Winters, L.A. 2000b, "Trade Liberalisation and Poverty", Discussion Paper No7, Poverty Research Unit, University of Sussex. 